DOI: $10.17516 / 1997-1370-0597$

УДК 314.747

\title{
"Returning Home as an Enemy". The Languages for Description and Self-Description of Inner Asia Repatriates
}

\author{
Ivan O. Peshkov* \\ Adam Mickiewicz University (Poznan) \\ Poznań, Poland
}

Received 07.03.2020, received in revised form 30.04.2020, accepted 08.05.2020

\begin{abstract}
The article explores the doubts and anxieties associated with the return of two communities of Russian long-term residents of Inner Asia - the Cossack repatriates of the Three Rivers Region and the local Mongolian Russians - to the Soviet citizenship. The theoretical basis of the article is the statement about the epistemological character of the presence of the past, which determines a crucial influence of the current terms on any historical knowledge. In this perspective, the memory of the past can be considered not only as its subjective reflection, but also as a social practice that identifies the community's status. The purpose of this article is to show how the Soviet people used speech practices in relation to the temporary and spatial discrepancy of repatriates. The main characters of this article will be the ways of creating an image of the enemy linguistically and mastering it by target groups in everyday life. In this perspective, the decision to repatriate, which causes distrust and alarm, is a convenient marker for the inclusion of local political folklore in the conflict between ethnic and political solidarity in Soviet society.
\end{abstract}

Keywords: China - Russia - Mongolia-frontier mythology.

Research area: social anthropology.

Citation: Peshkov, I.O. (2020). "Returning home as an enemy". The languages for description and self-description of inner Asia repatriates. J. Sib. Fed. Univ. Humanit. Soc. Sci., 13(5), 665-675. DOI: 10.17516/1997-1370-0597.

(C) Siberian Federal University. All rights reserved

* Corresponding author E-mail address: i.peshkov@wp.pl ORCID: 0000-0001-8923-1937 


\section{Introduction}

Let's imagine: the remote border regions of the 1970s USSR are dwelled by the Cossacks-like enemies, who live openly in a completely militarized and clear borders triangle - the USSR, Mongolia and China. They live together with the Soviet people or separately in the settlements, keeping a centuries-old lifestyle. They hate the Soviet regime, as well as the Soviet people; the bravest people among them cross the Soviet-Chinese border, going bold on the raids on the frontier posts and killing the Soviet soldiers. If they live in the Transbaikal territory, they aggressively get rid of the Soviet soldiers in the Cossack izba (log huts), being desperate to shoot at any Soviet thing. They are dressed in old-fashioned manner and armed. Though life keeps going on: the collective farms and factories are trying to execute the plan, soldiers are serving, and the parties of the border conflicts are ignoring the rebel ataman (the Cossacks' chieftain). Television, central newspapers - even "Zabaikalskiy Worker" - remain unvoiced. The truth, terrible and appealing, fragmented and hidden, was said people-to-people, turning the vast territory of Mongolia, Transbaikalia and the Chinese border territories into a space of strange and impossible events.

Despite the silence, chronic to the the Soviet people, someone must stand between the idyllic country and the enemy. The soldiers, specialists from other regions who came to Transbaikalia, the Soviet people in Mongolia regard such indifference of the locals as a partnership, or maybe even a conspiracy. They are not completely aware of how the state can give the Soviet citizenship to the white guards from Mongolia and China. What is the sense? A blind eye of the capital, which doesn't see all the specifics of the region? Underestimating the enemy's foul play and determination or a forced obligation to take home a superficially reformed enemies? The Soviet people are eager (or, mainly, forced) eliminate the state's mistake: the people from the past must remain there. They do not communicate with the local Russians in Mongolia and avoid the Chinese repatriates. The Soviet citizenship cannot be withdrawn, still it can be ignored - like an an- noying accident. Someone must tell the truth that "the enemy always remains the enemy".

This image is not a fiction of a graphomaniac writer or dreams of an officer who is tired of his pension time. This is a common and partially embodied model for the mass perception of events related to the implicit political and social alternatives in the Soviet, Mongolian and Chinese border regions. When facing such phenomenon, the first question is the status of the speech practices that make so huge retro-hallucinations possible.

The article describes a set of unexpected effects of the distrust to the post-war Mongolian and Chinese repatriates, that is reflected in the official Soviet dictionary. That sounds quite simply: the absence of a verified past and a common fear in the people who left the USSR by themselves - have led to practices of exclusion and mistrust. Most post-war repatriates, one way or another, encountered the same problems and their route to the homeland was not always so easy. Still, it is not that simple, as it might seem. The consequences mean the ability of speech to create a context that tear the time and space framework, owing to which not just long-dead enemies could become alive, but also the border territories again plagued into the Civil War mystery. Their unexpected nature was to declare that there were some areas in the Soviet Republics that were inhospitable to the Soviet power. Why then, in an era when "the signifiers are intentionally attached to the signified" (Humphrey, 2005: 337), it is possible to voice certain doubts in the most tolerate dictionary, that the state can guarantee internal safety? Why can the state's decision be thrown there into question? What is the language feature of an illegal fear of a created enemy in the time of "vegetarian socialism"?

The article aims finding the answer by investigating the return of two Russian old communities to the Soviet citizenship from Inner Asia, i.e. the Cossacks repatriates from the Three Rivers Region and the Mongolian Russians. Methodologically the article is based on the epistemological treatment of the past, which decisively causes influence of the contemporality on all the forms of historical knowledge (Kaplonski, 2010: 116-117). Both, in science and 
in the memoirs of "ordinary people", the meaning of the past (evaluations, lessons, emotional component) does not exist objectively and remains as a result of the experience interpreted through the prism of the present time. In this way, the memory of the past can be not only its subjective reflection, but also a social practice determining the community status. The article is aimed not at presenting a whole picture of the Soviet citizenship's semiotics, but - more modest - at showing how the Soviet people practice their language when speaking about the temporary and spatial inconsistencies of the repatriates. The linguistic means for the enemy image creation and for mastering it by the target groups in their everyday life are the focus of this article. In this way, a decision on repatriation, which rises concerns and mistrust, is an appropriate indicator for engaging the local political folklore into the conflict between ethnic and political solidarity in the Soviet society. The article relies on the field data obtained in the 2015 - 2016 fall in Mongolia, Inner Mongolia and Chitinskaya Oblast' are used.

\section{Calling for the past:}

\section{Soviet-China border stays the same}

The relations between language and reality are the basic interest for the social sciences, which cannot be satisfied through a simple referential-performative opposition in the description of the world (Agamben, 2018; Benveniste, 1966). The problem becomes even more complicated if the speech practices are past-centered: the physical absence of the referent (past) enables drawing the past closer by complex linguistic constructions, which links the tracks decoding, causality projections and emotional attitudes into a relatively uncontroversial whole. The combination of poor representation means and the endless scale of the unexpressed is universal and doesn't refer to the era of epistemological doubts, as well as to the end of grand narratives directly. Those societies, who maintain their memory by rigid teleological views, inevitably face the control boundaries both over the language of past representation and over its understanding (Zalejko, 1994). The Soviet society was not an exception. The sacralization of political language was not a panacea for doubts, irritation, and even for alternative views on the past. The analysis of dissident movement in the USSR shows that the "real Lenin" was no less dangerous than the dissident groups or "Voice of America" (Nikonova, 2008). The reduce of the traumatic past representations, available for the society, paradoxically caused new forms of representations that creatively use official discursive forms to get their own goals.

The Soviet people's collective imagination was mainly captured by the mythologies of three places of political and ethnic confrontation, i.e. the Bandera`s Ukraine, Semenov's Transbaikalia and Central Asia filled with the Basmachi bandits. In many ways, the followers of Semenov, Bandera and Basmachi were the ones who shaped the geography of political demonology of the Soviet frontier. Despite all the differences in time, places and culture, their dark legends were combined by the function of border management, - in other words they played a role of disciplinary narrative under the frontier socialism mode. Telling about the traumatic experience of the expansion of Soviet models of life, these legends were simultaneously a way of experiencing cultural hierarchies, fears, and a semi-conscious inner need for the material presence of the enemy. Their near-borders presence allowed considering them as a contact with something foreign and hostile in the Soviet perspectives. Therefore, unlike the classical enemies of the Soviet man, the border virtual non-communities (Zahra, 2010) were the groups of luminal creatures made of contradictions in the Soviet worldview. In this way, the post-Stalinist Soviet society was rather ready to create and use the enemies to experience complex time regimes and implement cultural hierarchies, than to eliminate them.

In the Soviet Transbaikalia, the collective imagination was mostly focused on the mythology of the Semenov movement. In the perspective of this legend, the public consciousness of the late USSR conceptualized alternative and less desirable models of the Russian culture and the opposition between ethnic and political solidarities (Peshkov, 2010). Being something close (representing a lost subculture) and act- 
ing as a semi-criminal anti-communist, a Semenovite was a complete stranger. The issues of metisation, anti-communism and territories untouched by modernization were raised within this discourse as an ideological context of absolute evil. Formal and informal stories about the cruelty of Semenov and his followers identified the Soviet Transbaikalia and an element of denial practices of decossackization and the long-term Old Settlers marginalization. Following this discursive logic, the denial practices reverse the context of events completely, representing the Communists repression as a form of public defense against a stigmatized group (Peshkov, 2010).

After Stalin's death, the stories about the Ataman and his followers became a collective retro-hallucination of a cross-border anti-communist resistance network in the region that threatens the Soviet people. The Soviet specialists in Mongolia, soldiers of the Transbaikal military okrug (district) and the Soviet population in Mongolia People's Republic, the migrants in Transbaikalia from other parts of the USSR, and even KGB (Community for State Security) officers are so mesmerized by the semi-official legend of the Semenovites' presence, that they start to recognize them in the marginal groups of Russian Old Settlers of Inner Asia, who had nothing in common with them. The problem of negative description of sterile and militarized border areas cannot be raised in simple categories of factual truth. One can assume, that the spatial representations of the world on the other side of the border combined with the temporal patterns enabled the possibility to meet with the difficult Revoloutionary past and its uncompromising imperative political definition.

As the Soviet soldiers in Transbaikalia and Mongolia remember, the Mongolian and Transbaikal periphery made it possible to see the Semenov's Cossacks settlements which were closed to the Soviet citizens. Such meetings with the enemy, rumors of closed stanitsa (Cossack settlements) and attempts to feel the enemy express both the unconscious willingness to recognize the enemy, as well as a imaginary geography of the Soviet frontier. Constantly repeated stories about the expulsion of the Soviet citizens from the Cossacks' own space, which remained untouched by the Sovietization, fixes a virtual Semenov's territory as a boundary between the modern life and the past that is completely lost. It should be noted that such a statement, which is undoubtedly a discriminatory practice, was still a form of symbolic exclusion, which was practically not supported by the repressive apparatus of the Soviet state. Paradoxically, this only strengthened the power of the legend, turning it into a semi-official knowledge of how things really look in the border areas.

Speaking on behalf of the dead, leaving them in the past - that is one of the main issues culture deals with. But haunting the past, one, to some extent, is haunting the dead, with their demands and their rights. The example of Antigone and Hamlet convince us that people are weak to imagine all the consequences of the dialogue with the past if one takes the dead's rights seriously. Even the instrumental use of return of the passed leads to new problems, such as the appearance of new communities, which "recognize" themselves in other people's biographies, or extreme politicization of other people's biographies that reproduces the past conflicts. By inhabiting the conventional border regions of Inner Asia with revived white guards, the Soviet society met the problem of how to treat their real or fake descendants.

\section{Genealogy of a non-community}

Where a non-community comes from? The historical prototype of the imaginary Semenov's non-community in Inner Asia was a part of the Transbaikal Cossack community, which supported the white guards in Transbaikalia and continued to fight against the Soviet power till the end of the World War II (Peshkov, 2012). After the anti-communist statehood in Transbaikalia was defeated, the most politically active part of emigration didn't stop their attempts to cross the border and continue fight in the USSR with the Chinese and Japanese military support. After the Kwantung army was crushed, the whole residence areas were forced to obey the Red Army and the NKVD (People's Commissariat for Internal Affairs) all this led to the fact that the Cossack emigra- 
tion's political activity was almost ceased. The Transbaikal Cossacks in the USSR and abroad were completely depoliticized, plaguing into the Soviet life or turning into a new emigrant community (the Cossacks from the Three Rivers Region), which oriented to peaceful coexistence with the Soviet government. Still, sterilization the border areas of Transbaikalia and Mongolia was not the end, but the beginning of a new history of the Semenovites' symbolic presence in the Soviet Transbaikalia, Mongolia and China. Surprisingly, inevitable de-militarization of the community took place at the same time with increasing of its symbolic role in the cultural policy of the Soviet Transbaikalia. Semenov's regime becomes the main official trauma of Transbaikalia: all the regional memorials commemorate the victims of the Ataman Semenov's rule. The real and fake crimes committed by the Semenovites are a crucial element in the Soviet Transbaikalia identification, as they create a picture of absurd kingdom of terror, which even now determine the perception of the region's history.

Then, what groups were recognized as the followers to the Ataman's dubious fame? First, they are the residents of the former Cossack settlements of Transbaikalia, the Mongolian Russians and the Russians (former and present) who live in the Three Rivers Region, in China. Among all this collection of groups, who often had no idea about each other, repatriation didn't touch the descendants of the Transbaikal Cossacks, who stayed in the USSR, and the contemporary Russians in China. Those who belonged to the first community were ordinary Soviet people, whose only difference was to preserve unofficial memories about the Civil War events: now the atrocities of the Semenov's were a wise (prosperous) attempt to protect the Cossacks from further sufferings, and the legendary heroes are analyzed on the basis of common origin. The second community (Chinese Russians) is a group which includes mainly the descendants of mixed China-Russian-Mongolian Orthodox families who live in the region at the present time. Their identity is based on the oral version of their history, made up of three traumas: the Civil War and famine in Transbaikalia, the Japanese occupation and the Cultural Revolution (Peshkov, 2014). Their memory of living together with the Cossacks is generally negative, they do not want to have anything in common with the "Cossack Vendée" (Basharov, 2010).

The local Russians in Mongolia represent a mixed community of the descendants of Russian peasants, Western Buryats, Cossacks and Chinese who escaped from the hunger and collectivization; it is recognized in the dictionary of frontier disloyalty (Mikhalev, 2008). Despite fighting in the Great Patriotic War and being generally loyal to the Soviet regime, the community was not able to overcome the negative image of being an implicit enemy. The rapid growth of the Soviet-Mongolian cooperation after 1966 caused a mass arrival of the Soviet specialists and military officers who were surprised by the existence of non-Soviet Russians in Mongolia. The story of Ungern-Sternberg Cossacks' descendants, hiding in Mongolia, is becoming the label of this community. Though they live with the Soviet citizens together but separately - nominally compatriots, but always perceived as former enemies. The complete recognition of their civil rights in 1979 did not change the situation: neither they, nor the soviet specialists noticed any changes. Alexei Mikhalev described the relations between the Mongolian Russians' civil status, historical experience of the frontier banditry and the community being used as a disciplinary mechanism as follows:

"(......) the local Russian were compared to the white guards and enemies. This model was easily naturalized because till the mid-1930s, there were the military units subjected to different atamans on the Mongolian border, who were engaged into the cross-border banditry. Such pattern which explains the origin of the local Russians stigmatized this community and set the task "to atone for the Motherland". This guilt was formed by the social exclusion - denied access to political rights or to profitable work, as well as the gaps in consumption and social distance. The latter was especially important because, as the guidance of the Soviet specialists says, "for communication with the local Semenovites, one will be deported to the mainland" (Mikhalev, 2016: 110). 
After 1991, the local Russians were no longer considered as the Semenovites, but remained aliens. Now they had to tackle the Transbaikal acculturation, manifested in non-classical Orthodox practices and visits to shamans and lamas. Such strange Orthodoxy is quite ironically becoming a new marker of exclusion: the former Communists demand canonical Orthodoxy from the former white guards.

The Cossacks-repatriates community of the Three Rivers Region was associated with the problematic region, social estate and time. The Three Rivers Region (Sānhé qū) is the Russian name for the delta of the three tributaries of the Argun River (i.e. Derbul, Haul and Gahn), which underwent an integrated agricultural colonization by refugees from the former Russian Empire and then became the main Russian agricultural center in China. Emergence of Manchukuo which led to semi-forced participation of the emigrants in protection of the border. (Perminov, 2008). All this completely demonized the community in the Soviet society's eyes. The aspect of real and mythical collaboration largely pre-determined the community life after the War. When the Kwantung Army was defeated, the local Cossacks began step by step moving to the USSR - first, as a forced deportation to the Soviet camps, and after Stalin's death, as a semi-forced repatriation with restricted rights for settlements in the Northern Kazakhstan and the Ural Region. Only in 1994, 15 families returned in Transbaikalia to the settlement of Senkina Pad', near Priargunskiy Rayon (District). It is worthy to note, that there was another emigration movement. Fearing repressions, a big part of the Cossacks emigrated through Shanghai to the USA, Canada, Australia and the Philippines, and arranged their own agricultural settlements there.

\section{The enemy after the Thaw}

What does it mean "to be an enemy after Stalin's death"? When the judicial category "the enemy of the people" disappeared (1958) ${ }^{1}$ it did not mean neither the old enemies vanished nor new ones stopped being created. Of course, a dramatic fall of political sentences,

\footnotetext{
Fixed in the Constitution till 1977 (Gutarova, 2012).
}

massive amnesties (caused by sentences restatements) and general optimism of the Thaw empowers the caesura of political repression. But the category "enemy" did not simply disappear from the political horizon, but rather took on new and, in most cases, unexpected forms. The massive return from the camps leads to new problems to families, employment, and to public places (Humphrey, 2010). A new round of the battle against religion, causes new victims, which cannot be compared with the Stalin's scale, but still very significant. The collective guilt undergoes a careful revision: most of the deported peoples can return to their small motherland, but some must patiently wait for their chance. This leads to the first dissidents and public creative communities' emergence that violates the party strategy.

In this perspective, despite that punitive measures are generally mitigated, the category of "enemy" becomes more complicated, in a new way combining the past, present and future in the people's perception. "Former people" are replaced by former prisoners and exiled men, often restricted in their rights on mobility and residence. The "enemy" becomes an anachronism that does not suit the "era of space and corn", which is marked by a brighter future vector. Obviously, not everyone can enter this future: the state still does not trust a huge number of people. Slightly changing the well-known words of Anna Akhmatova, both, "executed Russia" and "executing Russia", must look into the eyes of the state first, which suspect their executers as well as their victims.

There comes a new phenomenon: the society begins to outpace the state when recognizing the enemies. Thus, the disappearance of punitive vocabulary from the code of criminal procedure leads to a shift in the process of enemy creation. If the state must call the enemies allegorically (a sectarian, freeloader, distributor of prohibited literature or pervert), then the society takes the right to clearer the definitions over. O. Kharkhordin describes the shifting processes, which convert the maintenance to more subtle and horizontal and only strengthen this trend (Kharkhordin, 2016). But what is the status of the recognized enemy? Of course, through the lens of law, the enemy 
cannot be recognized without the state's sanction and support, i.e. it does not have any legal force and cannot be regarded as a performative act. But how do the society and the recognized groups treat that? In this case, the situation looks quite ambiguous. One should not underestimate these more simple and weaker forms of performative activity. The recognition creates a semi-fictitious control community and no less fictitious community of enemies. The reproduction of this regime does not result in the criminal prosecution, though may lead to long-term restrictions on the real rights and consent to exclusions. While direct forms of discrimination can theoretically be suppressed by the state involved in the discussion about the person's status, then more implicit forms of enemies distancing can occur automatically and still be not so much clear (Humphrey, 2010).

In this way, "the public legal creativity" shows increasing control of the society over the state (referring to the values of confrontation and clear friends-enemies distinction). One may ask a question about the mechanisms of creating new enemies. First, this relates to the people who had lived abroad and after 1945 were massively returning. Who were they? Were they innocent? Was it possible to redeem their past sins? The answers are not that simple as it may look. The emigration posed the questions about the attitude to the past on the territory of the enemy. How to measure involvement (which is compulsory) into the army of other state or into the work of political body, study at an intelligence institution, or just a quiet life away from a warring country (Ablazhei, 2007). How far they can be called "the Soviet citizens"? How can they prove their loyalty to the country? The Soviet Union received the right on a part of the emigration, but did the emigrants receive the right to live among us?

The answers were hard to find due to a new round of the Revolution and the Civil War cult, directly related to the attempts to bring Lenin back. The purity and humanism of revolutionaries put the framework of ethnic and political solidarity under discussion once again. The Civil War quite convincingly demonstrated that the ethnic solidarity does not guarantee political consent. This doubted the fact, whether people from the past had a right for a brighter future. The situation worsened by certain reactions to emotional blackmailing by the Soviet society. The problem was not the rumors about a happy life abroad: the former emigrants, except for the brave old Cossack women-repatriates, quickly understood the rules and restrictions. The problem lied in avoidance and silence [Humphrey 2005], reinforcing the idea that they had something to hide. The emotional atmosphere of the Soviet work did no imply silence, the silenced Russia of the prisoners and emigrants seemed a thrilling anachronism and nobody knew what to do with it. The encountered silence only increased distrust; avoiding conversation was a challenge that called the public's desire to understand who became one of them into question. This seems paradoxical, but such fear evoked a hidden voice and concealed thoughts: in the eyes of the society, avoiding confrontation looked like a confirmation of the deepest concerns.

When speaking "Russian emigration", one might not think of the rural refugees from Transbaikalia, patiently reconstructing the ruined village life in the border areas of Mongolia and China. The world of Cossacks, peasants, Old Believers and Christianized foreigners, fleeing hunger and repression, seems to be completely lost in the maelstrom of great events and dramatic changes in the frontier areas. Their life there, first, as incomprehensible, and then often negatively recognized communities, turned simple stories of the village life into a part of the massive process of the border territories filtration. It is the border that links the time and place into an insoluble substance made of suspicion, fear and negative thoughts. In this perspective, the former people of the Russian settlements in Inner Asia represent a forbidden life, condemned by the state and society to a collective name, responsibility and penance. They had no place in the state's fate and, thus, they were forever locked up by the official versions of its past.

The Soviet people's imagination demonized the local Mongolian Russians, fitting into this myth the normal features of the peripheral and agrarian group of the region: metisation, aggression and bilingualism. The "Semeno- 
vite" in Mongolia becomes a symbol: an aggressively disposed metis - a descendant of the Soviet power's enemies and the one who no longer related to the modern Russian culture. The response aggression towards the Soviet Union confirms the rumor, and the community's closed nature and its partial acculturation in the Mongolian culture leads to new mythologization. On the other hand, the local Russians accept this name by themselves, often not quite capturing its meaning. To put simply, they played a game, not feeling its rules. All attempts to compromise and unite with the compatriots are stopped even at the school level: the Semenovites and the Soviet people live in different styles and try not to meet each other. The people from the past evoke different feelings: fear, respect, contempt, hate, but not mercy and sympathy. Their feelings and intentions are vague, they are completely in the shadow of the imposed hostile image, which makes it impossible to be interested in their internal problems. One of my respondents described a life full of contradictions in two ways: a normal Soviet school girl in Mongolia and a recognized member of the enemy community: "We still do not fully understand why the Soviet people hated us so much. We just wanted to be and indeed were like them, but no one heard or took us seriously. We had to be enemies, traitors, descendants of the white guards". The transformation of peasant refugees (Scott, 2009) into fearsome enemies of the Soviet regime was supported by a lack of clear story about their experience. The group described in terms of exclusion (non-Soviet, non-Mongols, non-Chinese) has never become more than a regional community. Their memory concentrates on the horrors of the Civil War, hunger and hard life in Mongolia.

For the Cossack repatriates, the life in China and Kazakhstan grounds the group identity. Except a few senior members of the families born in Transbaikalia, the Manchurian experience has determined the community identity. Its memory is centered around a happy childhood and youth in the Three Rivers Region and the Soviet life. The first post-Cossack generation lives in an ideological vacuum: they are far from both the anti-communist movement and the USSR: being seized by the reality of living together with the Semenov's followers form the one side and the general negative Soviet stereotype of Semenov's from the other, their public memory focuses on a mutual drama of the Civil War and on "peaceful" aspects of their parents life in Manchuria (economics, religion, community). Indeed, contrary to the Soviet stereotype, the Cossacks of the Three Rivers Region and their descendants recognize themselves as a peaceful and politically passive group, which was the instrument of Japanese policy and became a victim of the Soviet and Chinese repressions. Their motherland met them with the black fame of the Ataman and the official label of being Semenovites. The lack of Soviet socialization and the real experience of life in the border areas made any dialogue impossible. The society did not want to hear about the past, and the repatriates did not understand the black-and-white picture of the Transbaikal disaster. For the community it was hard to learn the Soviet semiotic field: to speak the language of power (Kotkin, 1997), to remain silent (Humphrey, 2009) and to adapt narratives about the past to the capacities of the host society (Figes, 2007).

The popular Soviet version and its influence on the attitude of institutions-society relations cause de-politicization of biographies and family histories. The surnames and events used in the Soviet narratives (Semenov, Semenovites, collaboration with the Japanese army) are generally excluded from the dictionary and the main emphasis is put on universal neutral elements of the memories: family, religion and Chinese exoticism. Being unable to confront the Soviet propaganda machine, the group completely rejected the political components of the family history. The stories about the past of the Cossacks are aimed at opposing the Soviet cliché about the Semenovites' crimes to a semi-idyllic image of a peaceful and hardworking community. The complete de-politicization of the past was a natural reaction to the political conflict provoked by the Soviet society. The Soviet propaganda and the collective imagination of the Soviet people artificially politicized the group, considering them as anti-communists and enemies of the Soviet society. When they returned to the USSR, the group did not have 
any strong anti-Soviet position, and the crash of the Semenov alternatives was obvious.

One can state, that the de-politicization of narratives about the past strengthened its alienation in Soviet society, rather than led to the group's Sovietization. Being out of the policy sharpened the need for the family independence, religion and individual work ethics as the main criteria for the identity. After 1991, the community continued to distance from the post-Soviet versions of the Civil War, but, unlike the pro-Soviet residents of Transbaikalia, it finds the cause of the region's economic and social crisis in the politics of Soviet period.

The dangerous past of the border regions is haunting the Cossack-repatriate communities and the local Mongolian Russians in the unexpected form of symbolic exclusion, almost not supported by the repressive state policy. Both communities were weak to understand, much less to accept the projected collective guilt for the Civil War, representing typical agriculture of refugees. The lack of the Soviet socialization in the first case or the basic stigmatization in the second, leads to leaving and avoiding the political language through the family stories. In both cases, communities try to get away from the politics, constantly emphasizing their severe fate, hardworking nature and loyalty to the Russian culture.

\section{Conclusion}

The article analyzes the specifics of the Soviet practices of suspicion, restricting the border population through the prism of inevitable political impurity, using the experience of repatriates from Inner Asia as example. The communities captured by this phantom are not able to resist the language of accusation: they either do not understand the essence, or do not know how to speak the language of the Soviet memory. The complex temporality of the Soviet worldview made the past a realm of political struggle and sharply politicized almost neutral reactions: avoidance, silence, misunderstanding, or tiredness from a wild history of the border regions. In this way, the foreign guests immediately became "the people from the past", reinforcing the concerns and fears about the credibility to the Soviet state. Unlike the Stalin period, when panic and fear were a strictly planned performance of the loyalty, now we deal with the public initiative, only partially and with huge limitations supported by the state.

Even though a certain degree of distrust in the ethnic or political conformity of new citizens is almost universal, the described case highlights the intensity of the public demand from "normal" citizens for the doubts about the repatriates' loyalty. The described ways for creating and recognizing the enemy represent possible turning political actions into fantasies, silence, or even misunderstanding. In this perspective, the need for the enemy can be far from what the state expects and continues to be the main obstacle to reconciliation after a national catastrophe.

\section{References}

Ablazhei, N.I. (2007). S Vostoka na Vostok. Rossiiskaya emigratsiya v Kitae [From the East to the East: The Russian Emigration in China], Novosibirsk, Izdatel'stvo SO RAN.

Agamben, Dzh. (2018). Ostavsheesya vremya. Kommentarii k Poslaniyu k Rimlyanam [The Time Left: Commenting the Manifest to the Romans], Moscow, NLO.

Basharov, I.P. (2010). Russkie Vnutrennei Mongolii: kratkaya kharakteristika gruppy [The Russian of the Inner Mongolia: Brief Review on the Community]. In Aziatskaya Rossiya: migratsiya, regiony $i$ regionalizm $v$ istoricheskoi dinamike [The Asian Russia: Migration, Regions and Regionalism in History], Irkutsk, Ottisk.

Benveniste, E. (1966). Problèmes de linguistique Générale. Paris, N.R.F. Bibliothèque des sciences humaines.

Figes, O. (2007). The Whisperers: Private Life in Stalin's Russia. London, Allen Lane.

Gutarova, N.A. (2012). Ponimanie naroda - sub'ekta prava v sovetskoi politiko-pravovoi kontseptsii [Memories of the People - a Legal Subject in the Sovet Political and Legal Conception]. In Severo-Kavkazskii Yuridicheskii vestnik [North Caucasus Legal Vestnik], 1, 59 - 64. 
Humphrey, C. (2005). Opasnye slova: tabu, uklonenie i molchanie v Sovetskoi Rossii [Dangerous Words: Taboo, Avoidance and Silence in the Soviet Russia]. In Antropologicheskii forum [Anthropologic Forum], 3, $314-338$.

Humphrey, C. (2010). Postsovetskie transformatsii v aziatskoi chasti Rossii [The Post-Soviet Transformations in the Asian Part of Russia]. Moscow.

Kaplonski, Ch. (2010). Collective Memory and Chingunjav's Rebellion. In Khotogoydin Chingunzhav Tuuhiyin Sudalgaand, Ulan-Bator.

Kharkhordin, O. (2016). Oblichat' i litsemerit': genealogiya rossiiskoi lichnosti [To Accuse and to Dissimulate: Genealogy of the Russian Person]. Saint-Petersburg, Publishing House at European University at Saint-Petersburg.

Kotkin, S. (1997). Magnetic mountain: Stalinism as a civilization. Los-Angeles, University of California Press.

Mikhalev, A. (2008). "Russkii kvartal" Ulan-Batora: kollektivnaya pamyat' i klassifikatsionnye praktiki [The "Russian Ghetto" in Ulan-Bator: Collective Memory and Classification Experience]. In Vestnik Evrazii [Bulletin of Eurasia], 2, 6-28.

Mikhalev, A. (2016). Sozdavaya vraga: mestnorusskie v Mongolii [Creating the Enemy: The local Russians in Mongolia]. In Obozrevatel' [The Observer], 9, 105-119.

Nikonova, S.I. (2008). Inakomyslie i vlast' [Dissidence and Power]. In Izvestiya Samarskogo nauchnogo centra Rossiiskoi Akademii Nauk [Bulletin of Samara Research Center as the Russian Academy of Science], 10 (4), 1176-1180.

Perminov, V.V. (2008). Nakazanie bez prestupleniya [The Punishment without Crime]. Chita, Press Service of the Court Department in Chitinskaya Oblast'.

Peshkov, I. (2010). Granitsa na zamke postsovetskoi pamyati. Mifologizatsiya frontirnykh soobshchestv na primere russkih iz Trekhrech'ya [The Border Locked Down by the Post-Soviet Memory. Mythologization of the Frontier Communities through the Example of the Russians of the Three Rivers Region]. In Migratsii i diaspory $v$ sotsiokul'turnom, politicheskom i ekonomicheskom prostranstve Sibiri. Rubezhi XIX-XX i XX-XXI vekov [Migrations and Expatriate Communities in the Socio-Cultural, Political and Economic Space of Siberia $\left(19^{\text {th }}-20^{\text {th }}\right.$ and $20^{\text {th }}-21^{\text {st }}$ centuries $\left.)\right]$. Irkutsk, Ottisk.

Peshkov, I. (2012). Politization of Quasi-Indigenousness on the Russo-Chinese Frontier. In Frontier Encounters: Knowledge and Practices at the Russian, Chinese and Mongolian Border. Cambridge, Open Book Publisher.

Peshkov, I. (2014). Usable Past for a Transbaikalian Borderline Town. "Disarmament" of Memory and Geographical Imagination in Priargunsk. In Inner Asia, 16, 95-115.

Scott, J. (2009). The Art of Not Being Governed: an Anarchist History of Upland Southeast Asia. New Haven, Yale University Press.

Zahra, T. (2010). Imagined Non-Communities: National Indifference as a Category of Analysis. In Slavic Review, 69, 93-119.

Zalejko, G. (1994). Soviet Historiography as „Normal Science”. In Historiography between Modernism and Postmodernism. Contributions to the Methodology of the Historical Research. Amsterdam-Atlanta. 


\title{
«Вернуться на Родину врагом».
}

\section{Языки описания и самоописания репатриантов}

\section{из Внутренней Азии}

\author{
И.О. Пешков \\ Университет имени Адама Мииякевича в Познани \\ Польша, Познань
}

\begin{abstract}
Аннотация. Статья исследует сомнения и тревоги, связанные с возвращением в поле советского гражданства двух сообществ русских старожилов Внутренней Азии: казаков-репатриантов из Трехречья и местнорусских из Монголии. Теоретической основой статьи является положение об эпистемологическом характере присутствия прошлого, что обозначает определяющее влияние современных условий на историческое познание в его любых формах. В этой перспективе память о прошлом может рассматриваться не только как его субъективное отражение, но и как социальная практика, определяющая статус сообщества. Задача данной статьи показать, как советский человек использовал речевые практики по отношению к временному и пространственному несоответствию репатриантов. Способы лингвистического создания образа врага и его освоение целевыми группами в обычной жизни будут главными вопросами этой статьи. Вызывающее недоверие и тревогу решение о репатриации в этой перспективе является удобным маркером включения локального политического фольклора в конфликт между этнической и политической солидарностями в советском обществе.
\end{abstract}

Ключевые слова: мифология китайско-российско-монгольской границы.

Научная специальность: социальная антропология. 